\title{
Pendampingan Pengelolaan Keuangan Rumah Tangga Islami pada Guru SMKN 01 di Kabupaten Siak
}

\author{
Yessi Nesneri ${ }^{1}$, Irdayanti ${ }^{2}$, Anna Nurlita ${ }^{3}$ \\ 1,2,3Universitas Islam Negeri Sultan Syarif Kasim Riau \\ E-mail: yessi.nesneri@uin-suska.ac.id
}

\begin{abstract}
Abstrak
Pengelolaan keuangan rumah tangga Islami merupakan salah satu hal penting yang harus dilakukan oleh setiap rumah tangga muslim, dalam membantu mewujudkan keluarga yang harmonis. Pendampingan pengelolaan keuangan rumah tangga Islami pada guru SMKN $01 \mathrm{di}$ Kabupaten Siak bertujuan untuk meningkatkan pengetahuan masyarakat tentang pengelolaan keuangan rumah tangga yang Islami sesuai dengan konsep keuangan syariah. Kegiatan pengabdian masyarakat di awali dengan kegiatan persiapan pelaksanaan, yakni dengan survei kepada pihak sekolah dengan memberikan jadwal kegiatan dan materi yang akan didiskusikan kepada guru-guru. Kegiatan dilakukan dengan metode ceramah dan diskusi serta adanya praktik membuat perencanaan keuangan syariah. Materi berupa penjelasan tentang konsep pengelolaan keuangan rumah tangga Islami. Langkah-langkah mengelola keuangan berdasarkan konsep Islam, serta praktek membuat perencanaan keuangan yang sesuai dengan manajemen keuangan syariah.
\end{abstract}

Kata Kunci: Pengelolaan, keuangan syariah, rumah tangga islami

\begin{abstract}
Islamic household financial management is one of the important things that must be done by every Muslim household, in helping to create a harmonious family. Assistance in Islamic household financial management at SMKN 01 teachers in Siak Regency aims to increase public knowledge about Islamic household financial management in accordance with the concept of Islamic finance. Community service activities begin with preparation for implementation, namely by surveying the school by providing a schedule of activities and materials to be discussed with teachers. Activities are carried out using lecture and discussion methods as well as the practice of making Islamic financial planning. The material is in the form of an explanation of the concept of Islamic household financial management. Steps to manage finances based on Islamic concepts, as well as the practice of making financial planning in accordance with islamic financial management.
\end{abstract}

Keywords: Management, Islamic finance, Islamic household

\section{Pendahuluan}

Perekonomian Indonesia saat ini di hadapkan pada berbagai tantangan baik eksternal maupun domestik. Untuk menghadapi tantangan tersebut diperlukan berbagai strategi dalam rangka mengantisipasi pengaruh volatilitas perkembangan perekonominan global terhadap stabilitas perekonomian domestik, salah satunya melalui pengembangan ekonomi dan keuangan syariah. 
Pengembangan ekonomi dan keuangan syariah, tidak dapat dijalankan secara parsial. Sektor keuangan tidak dapat berkembang optimal tanpa pertumbuhan yang baik di sektor ekonomi(Supartoyo, Juanda, Firdaus, \& Effendi, 2018). Oleh karena itu untuk membentuk sistem keuangan yang baik maka sektor ekonomi terlebih dahulu harus di benahi melalui partisipasi dari setiap elemen masyarakat untuk memahami konsep money follow the trade yang merupakan pemahaman bahwa uang memainkan peran sosial (social role) dan uang mesti diinvestasikan pada kegiatan yang bertujuan mendorong keadilan sosial dan ekonomi serta membenahi nilai tambah bagi kesejahteraan individu dan masyarakat.

Kesejahteraan individu dan masyarakat dapat terlihat dari kesejahteraan keluarga, karena keluarga merupakan topangan dari jati diri, serta pembentukan jiwa manusia yang menjadi dasar sifat dan karakteristik seseorang dalam dunia sosial. Kestabilan ekonomi di dalam keluarga merupakan salah satu faktor yang cukup menentukan kebahagiaan dalam keluarga. Oleh sebab itu, untuk mewujudkan kestabilan ekonomi keluarga maka diperlukan pemahaman dan keahlian dalam kegiatan perekonomian keluarga yakni pengelolaan keuangan.

Pengelolaan keuangan pribadi dan keluarga dalam Islam di sebut Sakinah Finance(Endrianti \& Laila, 2016)yakni sebuah pengelolaan keuangan dengan menentukan skala prioritas dan anggaran rumah tangga yang menggunakan prinsip pola konsumsi Islami yang berorientasi pada kebutuhan (need) serta mendahulukan manfaat (utility) dan berusaha mengurangi keinginan yang berlebihan.Pengelolaan keuangan rumah tangga bagi keluarga muslim sangat penting dalam membantu mewujudkan rumah tangga yang harmonis dan mampu menjadi pendukung bagi aktivitas keIslaman dan keseharian rumah tangga yang Islami (Almizan \& Iswandi, 2018). Banyak kita temukan masalah ekonomi atau keuangan keluarga yang menjadi penyebab ketidakharmonisan dalam rumah tangga dan akhirnya mengganggu aktivitas seorang muslim dalam melaksanakan tugasnya, baik sebagai seorang istri, suami, atau anak untuk beribadah kepada Allah SWT.

Dalam kaidah fiqh, ekonomi keluarga mutlak tanggung jawab suami. Jika istri berpenghasilan, hasilnya untuk diri sendiri dan jika digunakan untuk mencukupi kebutuhan keluarga, maka bernilai shodaqoh. Rumah tangga, yang di dalamnya ada suami, istri dan anak-anak, merupakan unit keuangan yang terkecil. Pada umumnya saat awal menikah, sering terjadi kesulitan mengatur keuangan rumah tangga, yang berakibat terjadi 'deficit cash flow' pada akhir bulan, karena pengelolaan keuangan belum tertata dengan baik, dan belum ada perencanaan secara komprehensif (Ismayanti, 2018). Oleh sebab itu perencanaan keuangan menjadi pentinga untuk mencapai tujuan yang efektif, efisien, dan bermanfaat, sehingga keluarga tersebut menjadi keluarga yang sejahtera. Secara umum, aktivitas yang dilakukan adalah proses pengelolaan penghasilan untuk mencapai tujuan finansial baik saat ini maupun di masa depan.

Otoritas Jasa Keuangan (OJK) saat ini melakukan berbagai program untuk 
membantu meningkatkan pertumbuhan keuangan syariah salah satunya dengan menggalakkan program penerapan prinsip keuangan berkelanjutan (sustainable finance) yang merupakan program khusus untuk mendorong pertumbuhan lembaga keuangan syariah (Keuangan Berkelanjutan, 2019). Selain itu, OJK juga mendorong lembaga keuangan syariah untuk membentuk desa binaan keuangan syariah yakni dengan melakukan sosialisasi pengelolaan keuangan rumah tangga Islami.

Sosialisasi Pengelolaan Keuangan rumah tangga islami salah satunya bertujuan untuk meningkatkan kapasitas sumber daya manusia. Sumber daya manusia yang dimaksud dalam pengabdian ini adalah Guru (Rosyid \& Aris, 2016). Guru merupakan salah satu agen dalam perkembangan keuangan syariah. Guru diharapkan menjadi motor penggerak dalam pengembangan keuangan syariah. Mengingat guru juga merupakan tenaga profesional yang dapat merencanakan dan melaksanakan proses pembelajaran, pembimbingan dan pelatihan kepada masyarakat. Yakni dengan membentuk kelompok keuangan syariah agar masyarakat memiliki keahlian pengelolaan keuangan rumah tangga Islami sehingga terwujud keluarga yang mencapai falah.

Guru yang menjadi objek sasaran pengabdian ini adalah guru SMKN 01 Kabupaten Siak yang mana SMKN 01 merupakan sekolah yang secara khusus memberikan dan melatih keahlian yang lebih sfesifik di bandingkan sekolah menengah lain, hal ini tentu saja karena SMK merupakan sekolah Kejuruan yang mempersiapkan siswa untuk siap pakai di masyarakat. Selain itu SMKN 01 merupakan saatu-satunya sekolah menengah yang bersifat kejuruan di Kabupaten Siak yang banyak memerlukan bimbingan.

Sekolah Kejuruan Menengah Negeri 01 Kabupaten Siak adalah sekolah yang sedang berkembang dan butuh banyak pengetahuan untuk Guru-gurunya dalam rangka meningkatkan sumber daya manusianya. Agar peserta didik mampu bersaing, baik nasional maupun di kancah internasional. Selain itu kegiatan pengabdian ini selaras dengan Visi Kabupaten Siak yang menginginkan terwujudnya Kabupaten Siak yang Maju dan Sejahtera dalam lingkungan masyarakat yang Agamis.

Sikap Agamis masyarakat salah satunya ditunjukkan oleh seberapa patuhnya seseorang terhadap perintah agama yang dalam hal ini tentunya Keluarga. Sikap agamis pada dasarnya harus dibentuk dari lini terbawah yakni keluarga. Saat ini, masalah yang paling krusial yang dihadapi keluarga adalah masalah keuangan yang berakibat pada memburuknya kondisi perekonomian keluarga (Ardhi, 2017).

Berdasarkan hal tersebut, maka pendampingan pengelolaan keuangan syariah sangat urgen utuk dilaksanakan, agar dapat memperbaiki pola fikir masyarakat dalam mengelola pendapatan dan keuangan rumah tangga berdasarkan prinsip Islam. Menambah pengetahuan masyarakat tentang pengelolaan keuangan yang di awali dengan melakukan perencanaan keuangan dengan baik sesuai dengan konsep manajemen keuangan syariah. Di mana pendapatan bukan hanya digunakan untuk kegiatan konsumsi duniawi, namun lebih dari itu, yakni untuk mencapai mashlahah/manfaat dan berkah dunia dan akhirat. Melalui konsep pengelolaan 
keuangan rumah tangga Islami kepada guru juga untuk mendukung program Otoritas Jasa Keuangan (OJK) dalam mengembangkan Keuangan Syariah yang di mulai dari lini terpenting yaitu keluarga.

\section{Metode}

Pengetahuan pengelolaan keuangan rumah tangga Islami pada prinsipnya merupakan hal yang sangat penting dalam menjaga stabilitas perekonomian keluarga, oleh sebab itu untuk dapat melakukan pengelolaan keuangan rumah tangga yang Islami sesuai dengan konsep keuangan Islam maka diperlukan pengetahuan yang luas dan ini menjadi kegiatan yang di sajikan dalam kegiatan pengabdian ini. Pelaksanaan kegiatan Pengabdian kepada Masyarakat ini dilaksanakan selama 3 (tiga) hari dimulai dari tanggal 14 s/d 16 Oktober 2019. Kegiatan ini dilaksanakan di Aula rapat SMK N 01 Kabupaten Siak dimulai dari jam 09.00 s/d 16.00 WIB.

Kelompok sasaran kegiatan pengabdian masyarakat ini adalah para guru SMKN 01 Kabupaten Siak dengan peserta berjumlah 14 orang. Adapun jumlah peserta dibatasi agar dalam pelaksanaan lebih efisien dan tim dapat mengontrol dan mendampingi peserta dalam praktek penyusunan keuangan rumah tangga.

Tabel 1. Peserta kegiatan PPkM

\begin{tabular}{lll}
\hline No & Nama & NIP \\
\hline 1 & Hasanudin, S.Pd, M.M & 196411031991031003 \\
\hline 2 & Julitawati, S.Pd & 197902052006042005 \\
\hline 3 & Romi Kurniawan, S.Pd & 198106122010011016 \\
\hline 4 & Rasyid Rido, S.Pd & 198212022009031003 \\
\hline 5 & Achsin Rosidi, S.Kom & 198201042011021001 \\
\hline 6 & Zuriana, S.Pd, M.TPd & 197206131997022001 \\
\hline 7 & Fitriawati, S.Pd & 198006212008012021 \\
\hline 8 & Yusnelly, S.Pd & 197602072010012010 \\
\hline 9 & Nurdiana, S.Pd & 198411242010012015 \\
\hline 10 & Dastian Susila, SST,Par,M.Pd & 199101162015041002 \\
\hline 11 & Dian Rahmadani, S.Pd & 199103172015041002 \\
\hline 12 & Khusnul Khotimah, S.ST & 199102182015042001 \\
\hline 13 & Nurmala Juwita, S.Pd & 198909152015042001 \\
\hline 14 & Hendri Wahyudi, S.Pd,.M.Cs & 198103142010011011 \\
\hline & &
\end{tabular}


Langkah-langkah kegiatan dalam pengabdian ini melalui tahapan-tahapan berikut ini:

1. Riset Pendahuluan

Dalam riset ini pengabdi akan mengobservasi aktivitas sehari-hari guru, lingkungan sosial sekolah, dan kebiasaan para guru, dan yang terpenting adalah upaya mengetahui masalah. Riset ini berguna sebagai pijakan untuk masuk pada analisis lebih jauh. Riset ini juga akan mempermudah peneliti untuk melakukan langkah selanjutnya, yaitu inkulturasi.

2. Inkulturasi

Inkulturasi merupakan upaya untuk melebur dan membaur dalam kehidupan masyarakat sehari-hari. Informasi awal yang telah didapat ketika melakukan riset pendahuluan dapat dijadikan pedoman untuk mengadaptasikan diri di tengahtengah masyarakat. Dalam langkah ini, peneliti juga akan melakukan proses pendekatan sebagai upaya trust building. Maka dari itu, peneliti akan berusaha untuk bersikap netral, khususnya dalam hal golongan dan partai. Pendekatan yang akan pengabdi lakukan adalah melalui diskusi bersama guru SMKN 01 Kabpuaten Siak terkait kebutuhan yang mereka butuhkan dan permasalahan yang sedang mereka alami.

3. Pengorganisasian Masyarakat untuk Agenda Riset

Menentukan kelompok Sasaran, dalam hal ini adalah guru PNS yang akan menerima sertifikat yang juga bermanfaat bagi mereka untuk pengumpulan Poin.

4. Perencanaan Tindakan Aksi untuk Perubahan Sosial

Menentukan rencana kegiatan yang akan dilakukan dengan tujuan adanya perubahan dari permasalahan yang ada.

5. Aksi Hasil perencanaan

Aksi selanjutnya diimplementasikan secara simultan dan partisipatif. Pemecahan persoalan kemanusiaan bukanlah sekedar untuk menyelesaikan persoalan itu sendiri, tetapi merupakan proses pembelajaran masyarakat, sehingga terbangun pranata baru dalam komunitas dan sekaligus memunculkan community organizer (pengorganisir dari masyarakat sendiri) dan akhirnya akan muncul local leader (pemimpin lokal) yang menjadi pelaku dan pemimpin perubahan.

6. Evaluasi

Dilakukan dengan mengkroscek apakah yang telah dilaksanakan tetap berada dalam jalur yang ditentukan, bagaimana impresi dan efek yang dihasilkan. Jika ternyata langkah yang telah dilakukan membawa implikasi negatif dan destruktif, maka bukan tidak mungkin peneliti harus merubah arah kebijakan, karena sebenarnya PAR menghendaki pendekatan yang fleksibel dan multidimensional untuk menunjang progresifitas masyarakat.

7. Refleksi Informasi

Melakukan peninjauan secara terus-menerus, kemudian diklasifikasi, diverifikasi, disistematisasikan, dan terakhir diambil kesimpulan-kesimpulannya. Dengan 
demikian data-data lengkap yang telah tersusun menjadi bermakna. Berdasarkan hasil riset, proses pembelajaran masyarakat, dan programprogram aksi yang sudah terlaksana, peneliti bersama masyarakat merefleksikan semua proses dan hasil yang diperolehnya (dari awal sampai akhir). Refleksi teoritis dirumuskan secara bersama, sehingga menjadi sebuah teori akademik yang dapat dipresentasikan pada khayalak publik sebagai pertanggungjawaban akademik.

\section{Hasil dan Pembahasan}

\section{Riset Pendahuluan}

Sebelum upaya get in dengan guru sekolah SMK N 01 Kabupaten Siak, pengabdi melakukan riset pendahuluan sebagai penjajakan awal.Kegiatan ini dilakukan guna mengetahui kondisi dan fenomena yang terjadi di SMK N 01 Kabupaten Siak melalui obsevasi kepada Wakil Kepala Sekolah SMKN 01 Kabupaten Siak yaitu Bapak Achsin Rosidi, S.Kom.Berdasarkan observasi yang dilakukan, beliau menyatakan bahwa SMK N 01 Kabupaten Siak merupakan salah satu Sekolah Kelompok Pariwisata yang berdiri pada tahun 2013.Sekolah yang dinilai baru ini memiliki 30 Guru dimana 14 diantaranya adalah Guru PNS dan 16 diantaranya adalah guru kontrak atau non PNS. Disamping itu, guru-guru SMK N 01 Kabupaten Siak masih banyak yang baru dan muda, sehingga diperlukan ilmu pengetahuan baru untuk mengupgrade ilmu sesuai dengan perkembangan global saat ini.

\section{Inkulturasi}

Tim Pengabdi melakukan pendekatan kepada kepala sekolah, wakil kepala sekolah dan para guru guna mendapatkan informasi atas kebutuhan secara detail dan permasalahan yang dihadapai oleh para guru saat ini.Dari hasil inkulturasi ini, para guru melihat terdapat beberapa permasalahan ekonomi keluarga yang terjadi dimasyarakat Kabupaten Siak.Hal ini dikarenakan setiap keluarga jarang bahkan tidak pernah melakukan perencanaan pengelolaan keuangan rumah tangga dengan baik, dan hal ini akanberdampak kepada kesehatan ekonomi keluarga. Disamping itu, mereka melihat bahwa disekeliling lingkungan keluarga, terdapat bebrapa keluarga yang sudah beranjak usia 60 tahun keatas masih produktif dalam mencari mata pencaharian guna memenuhi kebutuhan hidup.

\section{Pengorganisasian Masyarakat untuk Agenda Riset}

Berdasrakan hasil inkulturasi sebelumnya, maka setelah Tim Pengabdian mendiskusikan permasalahan-permasalahan yang terjadi, dan solusi yang akan diberikan maka Tim Pengabdian menentukan tema kegiatan pengabdian kepada masyarkat ini adalah Pendampingan Pengelolaan Keuangan Rumah Tangga secara Islami. Pada agenda ini, tim memilih peserta pelatihan yang nantinya mampu berkontribusi kepada masyarakat Kabupaten Siak untuk mensosialisasikan agenda 
PPkM ini. Setelah melihat karakteristik dari para Guru SMK N 01 Kabupaten Siak, dimana jumlah guru SMKN 01 Kabupaten Siak adalah 30 orang yang terdiri dari 14 guru PNS dan 16 guru non PNS (Kontrak). Dengan ini maka tim memutuskan untuk memilih guru PNS dengan jumlah 14 orang. Pemilihan ini ditentukan atas dasar tercapainya tujuan dari pengabdian secara efektif dan efisien.Melihat jumlah anggota Tim Pengabdian yang berjumlah dua orang, maka dalam hal pendampingan pengelolaan keuangan rumah tangga ini agar berjalan efektif maka kami memilih guru PNS yang berjumlah 14 orang.Selain itu, melihat karakteritik dari guru non PNS atau kontrak yang sifatnya tidak tetap dan masih banyak yang belum menikah maka dipilihlah guru PNS yang notabene nya telah menikah yang memiliki tanggungan.

\section{Perencanaan Tindakan Aksi untuk Perubahan Sosial}

1) Memilih narasumber yang kompeten dibidangnya dan menentukan materi yang akan disampaikan.

Dalam kegiatan PPkM ini, kami melibatkan salah satu dosen bidang Manajemen Keuangan Syariah sebagai Narasumber untuk memberikan materi terkait Perencanaan dan Pengelolaan Keuangan Syariah yaitu Ibu Yessi Nesneri, SE,.MM dan beberapa materi seperti Perbankan Syariáh, Asuransi Syariáh, dan Pasar modal Syariáh. Tim PPkM juga terlibat dalam kegiatan diskusi bersama para peserta sekaligus membantu peserta dalam praktek penyusunan keuangan rumah tangga islami.

2) Menyusun kuesioner untuk pree test dan post test kegiatan pengabdian bersama narasumber.

Dalam hal ini kuesioner di kutip dari wesite OJK terkait dalam materi yang akan disampaikan. Dimana kuesioner tersebut sebagai alat ukur untuk mengevaluasi hasil dari kegiatan yang telah dilakukan.

\section{Aksi Hasil perencanaan}

Kegiatan ini dimulai dengan memberikan pretest kepada peserta terkait pengetahuan umum tentang manajemen keuangan, serta mendiskusikan permasalahan perindividu terkait pengelolaan keuangan yang telah mereka lakukan selama ini. Hasil pretest menunjukkan bahwa pengetahuan peserta akan manajemen keuangan masih kurang, hal ini terlihat bahwa dalam perencanaan pengelolaan keuangan rumah tangga, pengeluaran per bulan lebih besar dibandingkan pendapatan per bulan. Hal ini dikarenakan pola pemikiran dari peserta yang berpikir akan ada fee kegiatan tak terduga yang bisa menutupi biaya pengeluaran per bulannya. 


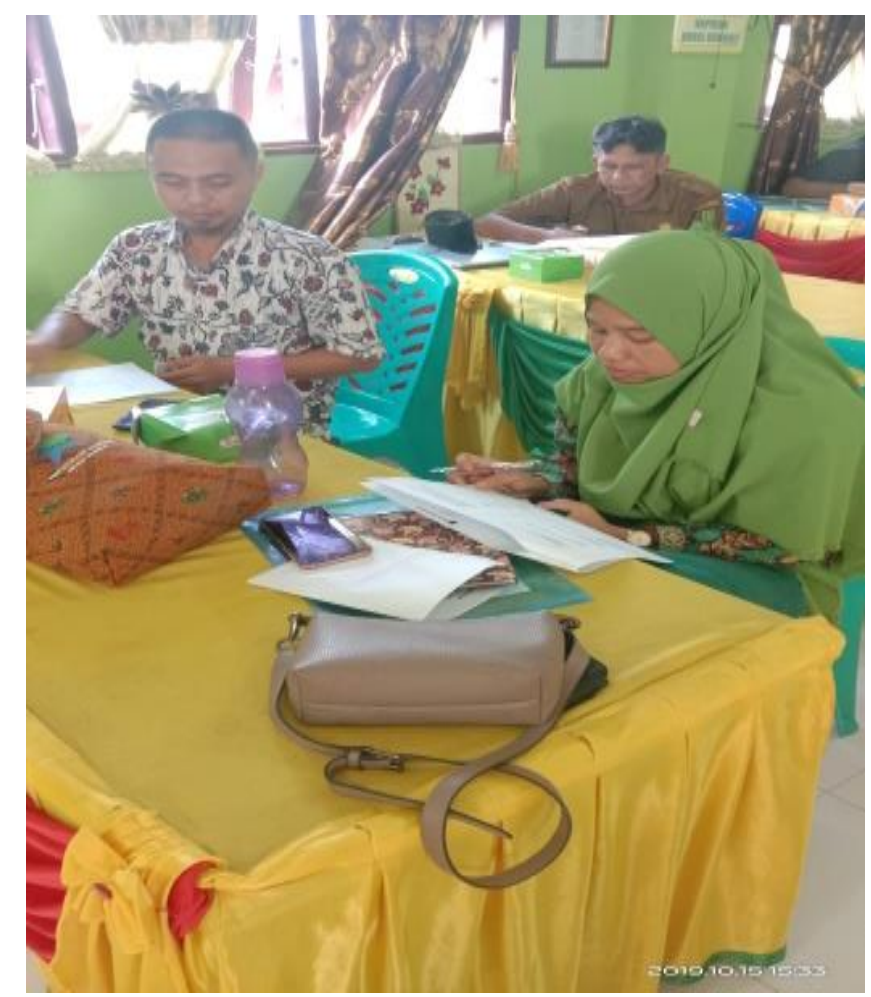

Gambar 1. Kegiatan pengabdian

Selanjutnya peserta membuat flowcash rumah tangga masing-masing yang dibreakdown antara pendapatan/penghasilan dan pengeluaran untuk setiap bulannya. Dari hasil diskusi dapat disimpulkan bahwa para peserta mayoritas memiliki pengeluaran yang lebih tinggi dari pendapatan/penghasilan yang mereka terima perbulan, dan untuk menutupi pengeluaran yang tinggi tersebut, peserta berharap ada fee yang mereka peroleh dari kegiatan-kegiatan yang sifatnya tak terduga.

Merujuk pada pada permasalahan tersebut, maka dalam kegiatan PPkM ini, narasumber memberikan pemahaman terkait instrumen keuangan yang bisa digunakan oleh masyarkat untuk mengelola keuangan rumah tangga yang islami, seperti adanya Perbankan Syariáh, Asuransi Syariáh, dan Pasar Modal Syariáh. Dari hasil diskusi ini diperoleh hasil, dimana para peserta masih menggunakan perbankan konvensional dan asuransi konvensional dalam mengelola keuangan. Kendala yang mereka hadapi adalah kurangnya pilihan perbankan syariáh di Kota Siak, dan distribusi ATM yang tidak tersebar banyak di beberapa titik di kota siak. Sementara, dalam hal asuransi dan pasar modal, peserta belum menggunakan dua istrumen karena kurangnya pemahaman tentang pentingnya asuransi dan pasar modal dalam pengelolaan keuangan rumah tangga. 


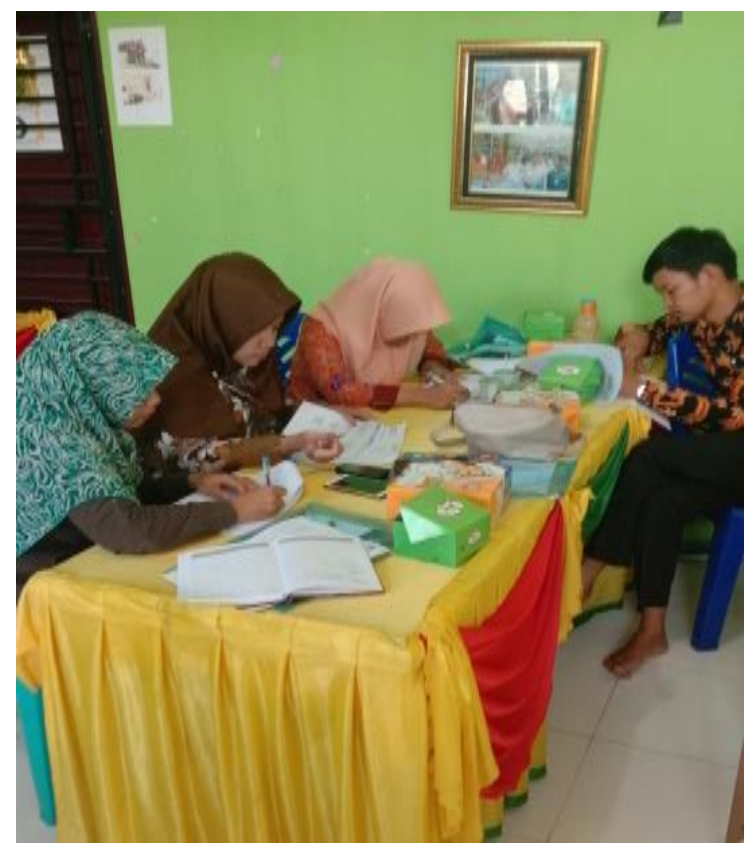

Gambar 2. Peserta mengikuti kegiatan dengan baik

Setelah memahami materi, peserta menyusun perencanaan keuangan rumah tangga yang disesuaikan dengan penghasilan/pendapatan yang mereka peroleh. Di akhir kegiatan menpresentasikan hasil perencanaan keuangan rumah tangga secara islami.

\section{Evaluasi}

Dalam mengevaluasi hasil yang dicapai dalam pengabdian ini, tim mengavaluasi hasil pengabdian pada hari ketiga dalam bentuk hasil rancangan keuangan rumah tangga islami yang telah disusun oleh masing-masing peserta. Hasil evaluasi pengabdian masyarakat ini dapat dilihat pada tabel di bawah:

Tabel 2. Evaluasi kegiatan PPkM

\begin{tabular}{|c|c|c|c|c|}
\hline \multirow[b]{2}{*}{ No } & \multirow[b]{2}{*}{ Kriteria } & \multirow[b]{2}{*}{$\begin{array}{c}\text { Indikator Pencapaian } \\
\text { Tujuan }\end{array}$} & \multicolumn{2}{|c|}{ Tolak Ukur } \\
\hline & & & $\begin{array}{c}\text { Sebelum } \\
\text { Pengabdian }\end{array}$ & $\begin{array}{c}\text { Setelah } \\
\text { Pegabdian }\end{array}$ \\
\hline 1 & $\begin{array}{l}\text { Pengetahuan } \\
\text { Masyarakat } \\
\text { Tentang } \\
\text { Pentingnya } \\
\text { Pengelolaan }\end{array}$ & $\begin{array}{l}\text { Masyarakat Memiliki } \\
\text { Pemikiran untuk segera } \\
\text { mengelola pendapatan } \\
\text { keluarga dengan prinsip } \\
\text { syariahagar mencapai } \\
\text { kesejahteraan keluarga }\end{array}$ & $\begin{array}{l}\text { Pola Pikir } \\
\text { Masyarakat } \\
\text { yang selalu } \\
\text { mengedepank } \\
\text { an keinginan } \\
\text { di bandingkan } \\
\text { kebutuhan }\end{array}$ & $\begin{array}{l}\text { Masyarakat } \\
\text { mampu } \\
\text { mengelola } \\
\text { pendapatan } \\
\text { keluarga } \\
\text { untuk } \\
\text { mencapai } \\
\text { falah }\end{array}$ \\
\hline 2 & $\begin{array}{l}\text { Pengetahuan } \\
\text { masyarakat } \\
\text { Pengelolaan }\end{array}$ & $\begin{array}{l}\text { Masyarakat dapat } \\
\text { mengelola keuangan } \\
\text { sehingga pendapatan }\end{array}$ & $\begin{array}{l}\text { Kelompok } \\
\text { sasaran tidak } \\
\text { mempunyai }\end{array}$ & $\begin{array}{l}\text { Kelompok } \\
\text { sasaran sudah } \\
\text { dapat }\end{array}$ \\
\hline
\end{tabular}




\begin{tabular}{llll}
\hline Keuangan & dengan pengeluaran & pengetahuan & mengelola \\
Rumah & seimbang serta tercapai & pengelolaan & keuangan \\
Tangga Islami & konsep mashlahah dalam & keuangan & menurut \\
& $\begin{array}{l}\text { perekonomian rumah } \\
\text { tangga. }\end{array}$ & rumah tangga & sistem \\
& & yang Islami & keuangan \\
& & & Islam. \\
\hline
\end{tabular}

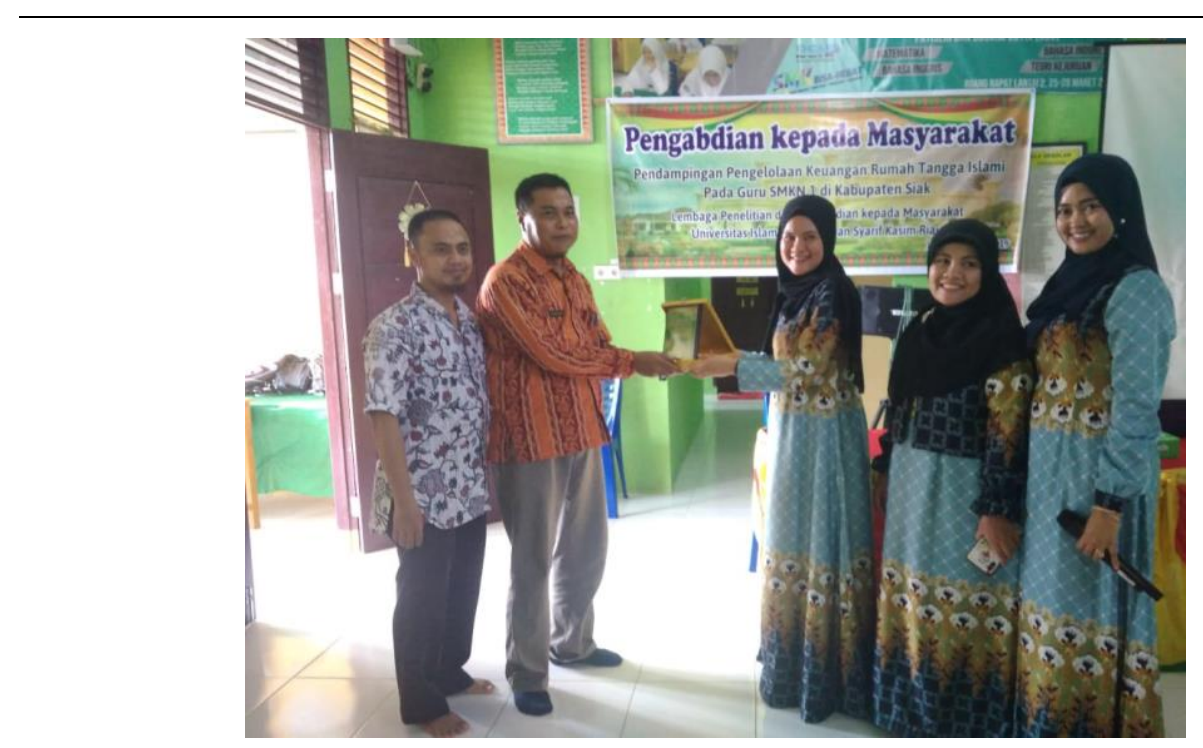

Gambar 3. Evaluasi kegiatan

\section{Simpulan}

Permasalahan umum dalam pengelolaan keuangan rumah tangga pada guru SMKN 01 Kabupaten Siak terletak pada tingginya pengeluaran dibandingkan penghasilan yang diperoleh.Hal ini disebabkan peserta belum mampu membedakan antara keinginan dan kebutuhan, dan para peserta tidak pernah meriview pengeluaran yang dilakukan setiap bulannya.Sehingga peserta tidak menyadari bahwa pengeluaran lebih besar dari pemasukan. Dari kegiatan yang telah dilakukan maka dapat disimpulkan: (a) Masyarakat dapat membedakan antara keinginan dan kebutuhan sehingga dapat menentukan skala perioritas; (b) Adanya perubahan Pengetahuan akan konsep keuangan syariah dari masyarakat dari yang belum mengetahui atau kurang mengetahui menjadi mengetahui. Namun dalam hal ini belum dapat dilihat pengaplikasiannya dalam kehidupan sehari-hari; dan (c) Masyarkat mampu membuat perencanaan pengelolaan keuangan rumah tangga yang islami. Namun dalam hal ini belum dapat dilihat pengaplikasiannya dalam kehidupan sehari-hari.

Berdasarkan hasil yang diperoleh tim PPkM maka kami memberikan saran kepada peserta agar: (a) Melakukan review atas pengeluaran dan pemasukan keuangan rumah tangga minimal per 3 bulan sekali; (b) Menerapkan rencana pengelolaan keuangna rumah tangga dalam kehidupan sehari-hari; dan (c) Mulai menggunakan lembaga keuangan syariáh dalam pengelolaan keuangan rumah tangga; dan (d) Diharapkan kepada peserta untuk memberikan pemahaman kepada masyarakat kota siak dalam pengelolaan keuangan rumah tangga islami melalui pembentukan kelompok keuangan 
syariáh. Selanjutnya saran kepada Pemerintah Kabupaten Siak yaitu: (a) Pemerintah dapat bekerjasama dengan beberapa lembaga keuangan syariáh sehingga tersedia pilihan lembaga keuangan syariáh di Kabupaten Siak; dan (b) Pemerintah mendukung dan membantu program pendampingan pengelolaan keuangan rumah tangga Islami untuk mendukung program Otoritas Jasa Keuangan (OJK) dalam mengembangkan Keuangan Syariah yang di mulai dari lini terpenting yaitu keluarga.

\section{Referensi}

Almizan, \& Iswandi, T. (2018). Perekonomian Rumah Tangga Muslim Terhadaktivitas Neraca Keuangan Rumah Tangga. \& Al-Masraf(Jurnal Lembaga Keuangan dan Perbankan, Volume 3, Nomor2.

Ardhi, K. (2017, Januari 17). Retrieved from Kesalahan Pengelolaan Keluarga Yang Sering Terjadi: https://www.akun.biz/tips-bisnis/kesalahan-mengelola-keuangankeluarga/

Endrianti, R. D., \& Laila, N. (2016). Pengelolaan Keuangan Keluarga Secara Islam Pada Keluarga Muslim Etnis Padang dan Makassar di Surabaya. Jurnal Ekonomi Syariah Teori dan Terapan , 549-560.

Ismayanti. (2018). Analisis Manajemen Keuanga Rumah Tangga Keluarga Nelayan (Studi Kasus di Pasar Terandam Kecamatan BBarus Kabupaten Tapanulis Tengah). Medan: UIN Sumatra Utara.

Keuangan Berkelanjutan. (2019). Retrieved from www.ojk.go.id: https://www.ojk.go.id/id/Pages/Keuangan-Berkelanjutan.aspx

Rosyid, M., \& Aris. (2016). Pemahaman Produk Bank Syariah Guru Pondok Pesantren Di Kabupaten Tangerang dan Sikap Menggunakan Produk Bank Syariah. Jurnal Islaminomic, Vol 7, Nomor 1.

Supartoyo, Y. H., Juanda, B., Firdaus, M., \& Effendi, J. (2018). Pengaruh Sektor Keuangan Bank Perkreditan Rakyat terhadap Perekonomian Regional Wilayah Sulawesi. Kajian Ekonomi \& Keuangan , 14-38. 